\title{
VINTE E DOIS POETAS POLONESES: UMA PEQUENA ANTOLOGIA DE POESIA EM TRADUÇÃO
}

\author{
TWENTY TWO POLISH POETS: A LITTLE ANTHOLOGY OF POETRY IN \\ TRANSLATION
}

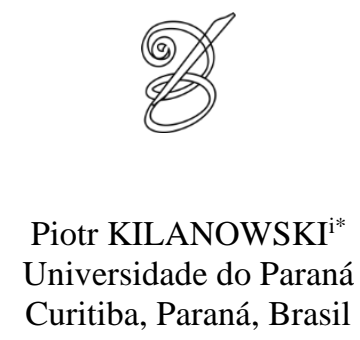

Resumo: Ao longo deste texto convidamos o leitor para fazer uma breve excursão pela poesia polonesa, desde os tempos renascentistas até o presente. O passeio, que conta en passant também a história da recepção e tradução da poesia polonesa no Brasil, foi construído subjetivamente apresentando a trajetória de seu autor (e tradutor dos poemas) pelos difíceis caminhos de traduzir poesia para o idioma que não é sua língua-mãe. A apresentação de vinte e dois poetas poloneses e seus vinte e dois poemas é também a apresentação de seu tradutor e de seus dilemas, das traduções e de suas perdas e ganhos.

Palavras-chave: Poesia polonesa. Tradução poética. História da literatura polonesa. História da tradução da poesia polonesa no Brasil. Literatura polonesa.

Abstract: Throughout this text we invite the reader to take a brief tour of Polish poetry from Renaissance times up to the present. The tour, which also shows en passant the history of the reception and translation of Polish poetry in Brazil, was built subjectively presenting the trajectory of its author (and translator of poems) through the difficult ways of translating poetry into the language which is not his mother tongue. The presentation of twentytwo Polish poets and their twenty-two poems is also the presentation of their translator and his dilemmas, of translations and its losses and gains.

Keywords: Polish poetry. Poetic translation. History of Polish literature. History of the translation of Polish poetry in Brazil. Polish literature.

RECEBIDO EM: 29 de novembro de 2019

ACEITO EM: 29 de janeiro de 2020

PUBLICADO EM: março 2020 
ideia desta pequena antologia - um passeio seletivo, subjetivo, tendencioso e
incompleto pela poesia polonesa - é apresentar aos leitores traduções de
importantes poetas poloneses. A seleção não só é pessoal e incompleta, como omite vários poetas notáveis, pelo simples fato de que ainda não estou satisfeito com as traduções que fiz de seus versos. O que norteou a escolha dos poetas reunidos foi, além do importante lugar que ocupam na literatura polonesa, minha afinidade com seus temas e a inclusão de nomes pouco conhecidos junto aos já celebrados por aqui. Sendo assim, acabei por omitir grandes românticos como Adam Mickiewicz ${ }^{\text {ii }}$, Juliusz Słowacki e Cyprian Kamil Norwid ${ }^{\text {iii }}$, poetas do grupo Skamander, como Julian Tuwim ${ }^{\text {iv }}$, e ainda outros poetas de várias épocas sem os quais qualquer antologia de poesia polonesa ficaria incompleta. É também devido a meus interesses que a grande maioria dos poetas selecionados pertence ao século XX e XXI e vários deles abordam o tema do Holocausto.

Sabendo que toda seleção é um motivo de polêmica, devo afirmar ainda que, dito de modo simples, essa pequena antologia é um registro daquilo que ainda jaz no fundo da gaveta do tradutor, aqui e acolá completado por poemas que já foram publicados. O registro está 32 ordenado cronologicamente e provido de comentários curtos, por força da limitação de espaço, sobre os autores e os poemas, e da indicação de outras publicações de seus poemas em português, quando é o caso. Espero que a leitura possa permitir uma pequena espreitada no amplo universo da poesia polonesa desde seus primórdios até os dias de hoje.

Os esforços para apresentar a poesia polonesa ao leitor brasileiro de uma maneira mais ampla tiveram seu início na obra pioneira de Henryk Siewierski, que introduziu essa poesia no português de Portugal ${ }^{\mathrm{V}}$ e no português brasileiro, primeiramente na revista Aproximações: A Europa de Leste em Língua Portuguesa ${ }^{\mathrm{vi}}$ e em várias outras publicações, algumas das quais estão referidas nas notas de rodapé. As duas antologias poéticas até agora existentes no Brasil foram colaboração de Siewierski com José Santiago Naud, no livro Quatro poetas poloneses ${ }^{\text {vii }}$ e com Marcelo Paiva de Souza, publicada na revista Poesia Sempre viii. $^{\text {ii }}$

Jan Kochanowski (1530-1584) ${ }^{\text {ix }}$ foi o pai do idioma literário polonês. O poeta renascentista, além de ter criado livros de Epigramas (Fraszki), também escreveu cantos a modo de Horácio e fazia poesia em latim. Traduziu os Salmos e foi autor do primeiro drama moderno polonês: $A$ dispensa dos emissários gregos, cuja ação transcorre durante o cerco de Troia. A sua obra mais famosa, Treny (Lamentos), é um ciclo de 19 epicédios no qual o poeta chora a morte de sua filhinha. A universalidade da dor humana cantada pelo pai entristecido nos permite encontrar 
em sua poesia elementos eternos com os quais facilmente cada um de nós se identifica. Ao mesmo tempo, a inovação de Kochanowski, o maior poeta eslavo da Renascença, foi dedicar o ciclo de epicédios a uma pessoa que não fosse notória e importante do ponto de vista público uma criança. No Lamento $V$, escolhido para esta pequena antologia, identificamos elementos de várias tradições presentes na obra de Kochanowski: as oliveiras, inexistentes na Polônia, e o estilo parabólico nos remetem à Bíblia, enquanto a presença de Perséfone testemunha o renascimento das tradições greco-romanas.

\section{Lamento V (Tren V)}

Como uma oliveira miúda, no alto pomar,

Seguindo a mãe, da terra ao céu tenta escalar,

Nem ramos, nem folhinhas ainda brotando,

Apenas uma varinha delgada galgando,

Que, na limpeza de urtigas e mato espinhoso,

Foi segada ao meio pelo hortelão ansioso,

Desfalece de pronto, da força inata privada,

Sem fôlego, cai inerte aos pés da sua mãe amada -

Assim aconteceu da minha querida Urszula a partida.

Diante dos olhos dos pais lentamente crescia sua vida,

Mal se levantou do solo, já pelo espírito contagioso

Da Morte Dura envolvida, dos pais amorosos,

aos pés caiu morta. Ó Perséfone atroz,

Quantas vãs lágrimas provocaste pela dor feroz.

Ignacy Krasicki $(1735-1801)^{\mathrm{x}}$ foi um dos representantes mais importantes do Iluminismo na Polônia, conhecido nos seus tempos como "O príncipe dos poetas", tanto por seu talento como por sua ascendência aristocrática. Bispo, senador, primaz da Polônia, amigo do último rei polonês Stanisław August Poniatowski e do rei prussiano Frederico II, Krasicki, além de ser um promotor de atividades culturais, foi também um patriota envolvido em política nos tempos difíceis da perda da independência polonesa. Foi autor, entre outros, dos primeiros romances poloneses Mikołaja Doświadczyńskiego przypadki (As aventuras de Mikołaj Experienciado, que continha elementos precursores de uma antiutopia) e Pan Podstoli (O Senhor Podstoli), da epopeia Wojna Chocimska (A guerra de Khotyn), poemas heroico-cômicos como Myszeida (Camundongueida), Monachomachia (Monacomaquia), Antymonachomachia (Antimonacomaquia), todos eles marcados pelo olhar satírico, didático, crítico de costumes e patriótico. Talvez, por todas essas características, as obras que ganharam mais popularidade e reconhecimento foram seus ciclos de sátiras e fábulas publicadas em três livros: Bajki $i$ 
przypowieści (Fábulas e parábolas, 1779), Satyry (Sátiras, 1779) e, em edição póstuma, Bajki nowe (Novas fábulas, 1802). É um clássico da poesia intelectualizada que observa a natureza humana e a critica no intuito de causar seu aperfeiçoamento. Além das obras literárias, foi profícuo tradutor e autor de extensa obra publicística. Exemplos nos quais ecoa o leme de Cândido de Voltaire são As cartas sobre os jardins, pois o poeta também foi um jardineiro apaixonado. Abaixo um exemplo das fábulas de Krasicki. Utilizando a linguagem de Esopo, sob os disfarces animais, observamos a impiedosa crítica das características humanas.

\section{O rouxinol e o pintassilgo (Słowik i szczygiel)}

O rouxinol silente, o pintassilgo criticou:

"Pena que cantas pouco". O rouxinol lhe replicou:

"O que me deu a natureza, eu cumpro fielmente.

Melhor pouco e bem, que longa e mediocremente".

Bolesław Leśmian (1877-1937) ${ }^{\mathrm{xi}}$ é, certamente, um dos mais interessantes poetas poloneses e de longe um dos mais originais. A densidade de sua poética lhe legou a fama de intraduzível. De fato, tentar traduzir Leśmian é sempre um desafio ímpar. Além de sua poesia juntar um imaginário inusitado com uma forma poética esmerada de grande densidade semântica, é um dos maiores neologistas da literatura polonesa. Nascido numa família judaica assimilada, Leśmian passou a juventude em Kiev e escrevia poesia também em russo. A poesia dele é marcada pela presença de elementos metafísicos, do resgate do folclore e do fantástico. É possível perceber nela influências de Bergson, Vico e Nietzsche. Poeta de várias faces, Leśmian foi autor de poemas eróticos e metafísicos, de baladas, nas quais se utiliza de um gênero fortemente ligado ao Romantismo, além de tentativas de resgatar o imaginário e as formas populares. Incompreendido e sem receber o devido valor, o poeta viveu às margens do mundo literário, sendo apreciado devidamente só depois da sua morte. Seus poemas, além de serem estudos metafísicos, são também, por vezes, estudos etimológicos que resultam em neologismos, alguns dos quais, com o tempo, passaram a integrar o idioma. O poema aqui apresentado é uma espécie de explicação da arte poética do autor. A poesia seria para ele a tradução de um impulso advindo da natureza para as palavras. O poeta seria uma espécie de médium que permite que o tal impulso tome corpo e permaneça invisível utilizando a palavra para melhor ver o mundo e vivendo-a em toda sua plenitude. 


\section{Reflexão (Zamyślenie)}

Quem me perdoará pra oráculos a inépcia?

Não sei da paixão de hoje, do vindouro canto...

A mão, qual a lã dum bicho, afaga a sem-querência

Dos cantos, cujo rosnado em mim acalanto.

Pelo rosnar reconheço que vieram da selva, Domestico-os e ensino meu falar, lentamente, Até a treva sibilante, ciciante e turva

Num grito l'azurado se tornar transparente.

Nos sussurros dos beijos - estão os meus lábios,

Nos barrancos soturnos - sopro da minh'alma,

Na choupana caída - meu pastoril cajado,

No remo dentro d'água - pro imo, a calda.

Adoro meus farrapos quando ensopados

De chuva, qual do choro do canto findante,

Mas não canto: da janela, com palavreado

Espio o mundo, de quem a abre, ignorante.

Que meus cantos, eles mesmos, por si se extagarelem,

Que eu não os extraia, mas em mim os viva!

Não quero dominá-los, nem corar por eles,

Apenas, como o Criador meu, ficar invisível.

Maria Pawlikowska-Jasnorzewska $(1891-1945)^{x i i}$ foi uma das primeiras vozes da poesia polonesa que levantou as bandeiras feministas. Filha e neta de conhecidos pintores poloneses (Wojciech e Juliusz Kossak), de família aristocrática e artística, a poeta cresceu e viveu nos meios criativos. Embora hoje permaneça conhecida principalmente por sua poesia, que tenta descrever sinteticamente o mundo do ponto de vista da perspectiva feminina, foi também importante dramaturga. Nas suas peças, temas como aborto ou relações extraconjugais escandalizavam a sociedade da época. Na sua poesia, os temas relacionados com emoções, principalmente com amor e desejo, vistas da perspectiva de uma mulher, assim como o tema da natureza, permitem vê-la como precursora da poesia feminista e da ecopoesia na literatura polonesa. Abaixo, uma das típicas miniaturas poéticas de Pawlikowska-Jasnorzewska que primam por conter o máximo de sentido nas poucas palavras e na forma minimalista. 


\section{É preciso andar de máscara (Trzeba chodzić w masce)}

fui de máscara e capa escura passear

com olhos estreitados

em foices radiosas

não me reconheceu a sorte

e me tirou para dançar

sem saber que era eu

que lhe era odiosa

e nem me reconheceu a sina

e pensou com manha

por que não agraciar

esta pessoa estranha

Zuzanna Ginczanka (1917-1945) ${ }^{\mathrm{xiii}}$ foi, assim como Pawlikowska-Jasnorzewska, uma das poetas mulheres que ficavam na órbita do famoso grupo poético Skamander, que unia os poetas mais badalados do período entreguerras polonês. Talvez uma das mais talentosas poetas dos anos trinta, não teve tempo de se desenvolver por completo. Nascida em Kiev, em uma família judaica assimilada, foi uma das musas dos cafés literários do fim dos anos trinta. Sua ascendência judaica foi o motivo de sua morte nas mãos dos alemães, depois de um longo período vivido em esconderijos no lado ariano. Seus poemas, além de celebrarem a vida, unem motivos mediterrâneos e judaicos com tradições eslavas, mitos germânicos e orientais. Assim como no caso de Pawlikowska-Jasnorzewska, há uma vertente em sua obra que fala do amor visto da perspectiva feminina. Ginczanka estreou com livro O centuarach (Sobre centauros), em 1936. A guerra impediu a publicação de seu segundo livro. Seus poemas celebram também o corpo feminino, e, num gesto de rebeldia contra a formação burguesa, por vezes, têm como tema principal sua fisiologia. Embora o poema mais conhecido de Ginczanka seja um tocante testemunho da vida em fuga dos perseguidores nazistas, denunciando as traições de que foi vítima, optei por apresentar aqui um dos poemas escritos antes da guerra, que fala da traição amorosa. Bem diferente das traições que iriam acabar por levá-la ao fuzilamento um pouco antes de completar 28 anos, o poema anuncia a independência feminina e o direito da mulher de viver sua vida afetiva de forma livre. A liberdade de trair, ou seja, a liberdade de viver os próprios sentimentos independentemente das convenções sociais, algo que até hoje é objeto de moralismos variados, é celebrada aqui como uma afirmação de independência. 


\section{Traição (Zdrada)}

Ninguém irá me conter.

$O$ pecado de camurça e morcegos

pendeu nos sótãos do medo, a cabeça de catita, pro chão -

Da torre ao ocaso me esgueiro, da forte torre escapo,

por entre as vespas iradas

e ervas letais no cercão -

Levantam dos escombros opressivos

os penhascos dos mandamentos,

os vinte infernos de Vedas,

as chamas,

os uivos,

e o ranger,

a noite fanática ameaça, apedreja com as estrelas,

Qual mercúrio deslizo entre os dedos.

Nada irá me conter.

Você se transforma em lobo e eu em alvéloa,

você em águia e eu em maravilhas espirais,

com fitos impenetráveis, impeço cada acosso seu.

Amado, caro, querido,

O mundo não irá me conter,

Se eu não quiser

Eu mesma

Na doce primavera

Ser fiel.

Wladysław Szlengel $(1912-1943)^{\text {xiv }}$ foi mais um dos poetas que deveriam ser chamados de representantes da geração dos Colombos (mais sobre eles na apresentação de Tadeusz Gajcy adiante), mas dificilmente é associado com ela, embora até cumpra o critério de ter participado da resistência, que alguns colocam como diferencial da geração. Szlengel já estava beirando os trinta quando eclodiu a guerra. Além disso, o poeta ficou à margem da historiografia literária polonesa, pois se identificava como judeu, embora escrevesse em polonês. O resgate de sua obra e nome na Polônia vem acontecendo desde os anos oitenta. Antes da guerra, foi autor de letras de músicas, que até hoje funcionam como bordões e motes na linguagem popular, mas cujo autor é desconhecido do público, e de poemas satíricos publicados em jornais. A maioria de seus poemas daquela época tem como tema central a situação dos que, como ele, sentiam-se ao mesmo tempo poloneses e judeus e tiveram que conviver com intolerâncias. Durante a guerra, Szlengel foi prisioneiro do gueto de Varsóvia, onde apresentava programas satíricos e escrevia poemas que lhe trouxeram a alcunha de "o poeta do gueto de Varsóvia". Devido à sua 
capacidade de usar uma linguagem popular, criando bordões que se fixavam na memória, os poemas de Szlengel estavam na boca dos habitantes do gueto, embora não pudessem ser publicados de maneira oficial, sendo transmitidos oralmente ou por meio de impressos clandestinos. Szlengel foi assassinado pelos alemães durante o Levante do Gueto. O poema escolhido aqui, proveniente do livro A janela para o outro lado, é um testemunho de como a palavra sobrevive aos extermínios e onicídios. Quando Halina Birenbaum, sobrevivente do gueto e de Auschwitz, resenhou, nos anos oitenta, para uma revista israelense, o primeiro livro de Szlengel publicado em 1979, falou de um poema até então perdido, citando de memória apenas algumas partes de que se lembrava. Um ano depois da publicação da resenha, recebeu uma carta de uma pessoa que encontrou a íntegra daquele poema entre os papéis recebidos de um amigo depois da guerra. A maioria dos poemas de Szlengel que sobreviveu ao Extermínio tem histórias fascinantes para contar, sobre como o papel e a palavra sobrevivem a incêndios e morticínios.

\section{Acerto de contas com Deus (Gueto de Varsóvia, 1943) (Obrachunek z Bogiem, Getto Warszawskie, 1943)}

Talvez fosse um sonho (que nada),

Talvez embriaguez que deu certo,

Sentamos juntos, eu e Deus,

Fazendo os nossos acertos...

Deus era um senhor de idade

Com os olhos de graça cheios,

Com a longa barba grisalha,

Andava sem braçadeira.

Não tinha consigo Kennkarta,

Pois veio do Éden, direto,

Mas tinha cidadania...

Do Uruguai, eu suspeito

Tirei um livro enorme,

Deus tirou a caneta-tinteiro

Abri a conta - fé

E disse... meu senhor sobranceiro,

Estou com trinta e dois anos, gordos e pobres anos meus,

Eu tinha o crédito aberto

até agora, meu Deus

Diziam: reze

Eu rezava

Diziam: jejue -

- jejuava...

Nos dias de jejum, duros,

Sem gota de água na boca 
Para a sua maior glória

e leis inventadas e loucas

No fumo de velas enfadonho

Em sinagogas arruaçadas

Rezava para que possa

os feitos meus ter contado

Diziam: não roube

não roubava

Diziam: não coma porco

não comia (mas gostava)

Diziam: Deus quer assim

Diziam: desígnios Seus

Diziam: não adultere

Eu me contive...para Deus

Diziam: não mate,

não matava.

Não tenha deuses além d'Ele

não idolatrava...

Há festas bem felizes

Há festas de penar

Todo ano, dez vezes,

Mandavam-me lembrar

Mandavam fazer as penitências

Mandavam sentar na sucá

deixar de lado o trabalho

Ingerir o amargo e o matzá

Com couro apertava o braço

Os livros à noite devorei

mortificava o corpo

Perdão, pergunto para quê?

Falava: Deus há de ajudar

Falava: Deus me garante

Cria: Deus há de salvar

Falava: e assim por diante...

Vem, olhe! Espie no livro

É claro como o dia

Comigo a página de seus

méritos - toda vazia...

Esbofeteiam meu rosto

- Não fujo como animal caçado

de uma toca a outra,

Espero... E você - nada...

Faminto, com frio e saudoso

Caminho tão longo, austero,

Vazio morto em volta

Não choro... - ainda espero...

Os cem milhares de rezas

Súplicas, jejum e lamentos,

o meio milhão de "améns" - 
jogados aos quatro ventos,

O que você me dá hoje

Por todos os meus feitos bons

O bloco... a placa... a praça

Treblinka ou os cupons?

Esperava ainda que eu

Amanhã como legado

Indo para o gás prússico

"Amém" tivesse falado?

Pode falar, por favor -

Me mostre a conta escondida

Os livros abertos - olhe! -

Parceiro da minha vida...

$O$ velho senhor agradável

Com quem bebi na mesa

Pegou um lápis e disse...

- aí acordei com surpresa.

Se era um sonho comum?

Se a bebida deu certo?

Não sei ainda até hoje

No que é que deu o acerto.

40 Czesław Miłosz (1911-2004) $)^{\mathrm{xv}}$ - foi um dos gigantes da poesia polonesa do século XX.

Laureado com o prêmio Nobel de Literatura em 1980, seu nome já dispensa maiores apresentações. A sua obra poética já foi apresentada algumas vezes ao leitor brasileiro. O poema selecionado é um testemunho e uma reflexão poética do autor que está do lado "ariano" do gueto de Varsóvia no momento do seu Levante, seguido pela destruição completa do bairro e do extermínio de seus habitantes. O poema, uma reflexão universal sobre a indiferença dos que não estão sendo atingidos pela morte e sobre o papel da poesia como um dispositivo de compaixão e rebeldia, foi escrito, coincidentemente, e sem saber disso, no momento da morte de seu coetâneo, um poeta cujas palavras incitaram a revolta no gueto, Władysław Szlengel.

\section{Campo di Fiori (Campo di Fiori)}

Em Roma no Campo di Fiori

As cestas de limões e azeitonas,

A calçada respingada com vinho

$\mathrm{E}$ as flores despedaçadas.

Os frutos do mar rosados,

Os feirantes espalham nas mesas,

As pencas de uvas escuras

Resvalam na penugem dos pêssegos.

Foi aqui, justo nesta praça 
Que queimaram Giordano Bruno

$\mathrm{O}$ algoz acendeu a pira

Cercado por turba curiosa.

E assim que baixaram as chamas

Já estavam cheias as tabernas,

Levavam nas cabeças, os feirantes,

As cestas de limões e azeitonas.

Lembrei-me do Campo di Fiori

Junto ao carrossel em Varsóvia,

$\mathrm{Na}$ tardinha de primavera

Ao som de uma canção saltitante.

As salvas trás o muro do Gueto

A canção saltitante abafava

E casais lá no alto voavam

No céu sereno e limpo.

$\mathrm{O}$ vento das casas em chamas

Trazia pipas negras às vezes,

Pegavam no ar os retalhos

Os que iam no carrossel.

Levantava as saias das moças

$\mathrm{O}$ vento das casas em chamas,

E ria o povo alegre

No lindo domingo de Varsóvia.

A moral alguém interpreta

Que o povo varsoviano ou romano

Negocia, diverte-se, ama

Passando por piras de mártires.

Outro a moral interpreta

Que fugazes são as coisas humanas

Que o esquecimento já cresce

Quando nem se apagaram as chamas

Mas eu naquela hora pensava

Na solidão dos que morrem.

Pensava que quando Giordano

No cadafalso subia,

Não achou em língua humana

Nenhuma palavra adequada,

Pra dar adeus a humanidade,

A humanidade que fica.

Já iam entornar os cântaros,

Vender as estrelas do mar brancas,

As cestas de limões e azeitonas,

Levavam na algazarra alegre.

E ele estava deles distante, 
Como séculos tivessem passado,

E eles esperassem um momento

Para vê-lo voando das chamas

E aqueles, morrendo solitários,

Pelo mundo já esquecidos,

Nossa língua agora estranham

Como a língua de um planeta antigo.

Tudo será lenda um dia

E então, muitos anos passados

Causará a palavra do poeta

A rebelião num novo Campo di Fiori.

Varsóvia - Páscoa, 1943

Tadeusz Gajcy (1922-1944) ${ }^{\mathrm{xvi}}$ é um dos poetas da geração denominada na historiografia literária polonesa como Colombos. O nome refletia a descoberta de um mundo terrível, de um ser humano reduzido a suas dimensões animalescas pela guerra e pelos totalitarismos. Os Colombos compunham a geração criada com patriotismo e idealismo excessivos; foi a primeira geração nascida na Polônia, depois que ela, após longo período, recuperou sua independência. Embora normalmente se pense nos Colombos como sendo os representantes daquela geração que morreram durante a Segunda Guerra Mundial, prefiro entender como Colombos também os que sobreviveram, mas cuja obra foi marcada por aquela experiência. E ao lado de seus representantes mortos, como Tadeusz Gajcy ou Krzysztof Kamil Baczyński, e dos que morreram e foram omitidos, como o poeta do gueto de Varsóvia Władysław Szlengel, acredito que seja preciso incluir entre eles poetas como Zbigniew Herbert, Wisława Szymborska, Tadeusz Różewicz, Jerzy Ficowski ou Tadeusz Borowski. Tadeusz Gajcy em seus versos, assim como um outro grande poeta morto no Levante de Varsóvia, Krzysztof Kamil Baczyński, concilia em seus poemas a convicção da necessidade de lutar contra o inimigo e a consciência de que a luta armada desumaniza. $O$ frescor da juventude em seus poemas é acompanhado pelo imaginário apocalíptico, a vontade de viver e amar é maculada pelo pressentimento da morte. O poema que aqui apresentamos é o último escrito pelo poeta. Foi encontrado junto ao seu corpo e refere-se a uma cena terrível que ocorreu durante o Levante de Varsóvia: um carroforte-armadilha foi deixado pelos alemães para ser levado pelos insurgentes e o material inflamável plantado nele acabou explodindo na estreita rua Kiliński, na Cidade Velha de Varsóvia provocando um massacre da população civil e dos insurgentes. A amarga ironia do poeta revisa também os ideais aos quais foi fiel como membro de uma organização nacionalista. Antemurale refere-se ao nome Antemurale christianitatis. Inicialmente o termo referia-se aos 
países que faziam fronteira com o Império Otomano em expansão, para em certo momento tornar-se uma forma de a diplomacia polonesa marcar o pertencimento do país ao Ocidente, sendo uma espécie de guarda de fronteira da cristandade e, portanto, um país pertencente ao Ocidente protegendo-o das invasões bárbaras. O termo "o Cristo das Nações" refere-se ao imaginário messiânico oriundo do romantismo, de acordo com o qual a Polônia era o messias das nações, que sofria a escravidão para que os outros países pudessem ser livres. Os mitos nacionais no último poema de Gajcy ganham ares grotescos e tenebrosos. Um representante da geração dos Colombos em seus últimos momentos, lutando contra o invasor alemão, percebe o uso dos mitos na educação nacionalista, que levou milhares de jovens a sacrificar inutilmente suas vidas no altar das brigas políticas, e zomba da sua retórica.

\section{Santo chef do Hipinho (Święty kucharz od Hipciego)}

Santo chef do Hipinho,

Todos os santos, eis a mesa!

No céu, festa: das sarjetas

de Varsóvia,

vem tripinha à polonesa!

Salsichões enchem bacias,

Fresquinhos, crocantezinhos,

Direto do Antemurale!

Cheiram a cadaverzinho!

À festa, santos, à festa,

Da Saturnália participem -

O Cristo das Nações é hoje

servido como acepipe!

Tadeusz Różewicz (1921-2014) ${ }^{\mathrm{xvii}}$ foi sem dúvida um dos maiores poetas poloneses do século XX, um dos principais responsáveis pela revolução do idioma poético polonês do pós-guerra. A simplicidade - para não dizer crueza - a opção pela linguagem coloquial e a abdicação de recursos poéticos tradicionais fizeram com que sua poesia fosse frequentemente chamada de antipoesia. Na tentativa de criar um idioma para a poesia pós-Auschwitz, no entanto, Różewicz conseguiu forjar um meio de expressão de extrema força e capacidade comunicativa. A palavra, que perdeu força e sentido com o apocalipse vivido na guerra, na poesia de Różewicz, justamente pela sua simplicidade, recupera sua força por ser direta, precisa e privada de adornos. Sem dúvida, esse representante da geração dos Colombos foi uma presença de extrema importância para a literatura polonesa, também devido à sua obra dramatúrgica vasta, revolucionária e provocadora. O poema escolhido, proveniente do livro Niepokój (Inquietação), 
publicado em 1947, talvez seja o mais conhecido do poeta. Ilustra bem a situação tanto do autor quanto de sua geração que, tendo sobrevivido à guerra, precisam reencontrar o sentido da vida, sendo obrigados, ao mesmo tempo, a questionar toda a herança cultural e tentar construir algo novo no lugar vazio.

\section{Sobrevivente (Ocalony)}

Tenho vinte e quatro anos levado para a chacina sobrevivi

Esses são nomes vazios e unívocos:

homem e animal

amor e ódio

inimigo e amigo

trevas e luz.

Matam um homem como um animal, eu vi:

carroças de pessoas esquartejadas

44 que não serão salvas.

Os conceitos são apenas palavras:

virtude e iniquidade

verdade e mentira

beleza e feiura

coragem e covardia.

O mesmo pesam a virtude e a iniquidade

eu vi:

o homem que era único

iníquo e virtuoso.

Procuro um preceptor e mestre

que me devolva a visão o ouvido e a fala

que outra vez nomeie as coisas e os conceitos

que separe a luz das trevas.

Tenho vinte e quatro anos

levado para a chacina

sobrevivi

Aleksander Wat (1900-1967) ${ }^{\mathrm{x} v i i i}$ foi sem dúvida um dos poetas mais interessantes e eruditos do século XX polonês. Nascido em uma família judaica assimilada, Wat teve a vida marcada pelos acontecimentos daquele século cruel. Primeiro, na sua fase que foi classificada como 
futurista ou dadaísta, em seu livro de estreia de 1919, foi precursor da escrita automática, antes de Breton proclamar a ideia para o mundo. Depois, envolveu-se com futuristas e o comunismo, redigindo a revista que foi um dos porta-vozes da ideia, sendo preso por isso. A guerra encontrou Wat em Lwów (Lviv de hoje), onde esteve livre dos perigos oferecidos pelo ocupante nazista, mas, em compensação, tendo sido obrigado a viver sob a ocupação de outro invasor a União Soviética. Não demorou muito para que o antigo comunista se tornasse prisioneiro do sistema, primeiro em Lwów e depois na prisão da NKVD na Lubianka, para, por fim, ser deportado para o Cazaquistão, assim como seus familiares, que, milagrosamente, Wat acabou encontrando por lá. Depois da guerra, voltou para a Polônia, onde desenvolveu uma enfermidade que creditou aos tempos de envolvimento com o comunismo e às prisões soviéticas. O poeta sentia dores excruciantes constantemente. Devido a um pequeno derrame, Wat tinha um microcoágulo alojado na área cerebral responsável pela dor. À procura de cura e fugindo do sistema, emigrou para o Ocidente, onde acabou por se fixar. A dor constante que impedia a vida normal provocou o suicídio do poeta. Além dos poemas e contos, sua obra mais interessante é uma entrevista-rio com Czesław Miłosz Mój wiek (Meu século), na qual Wat conta ao amigo poeta sua vida, resultando em mais um testemunho do cruel século $\mathrm{XX}$. A retradução do poema escolhido para apresentar Wat é um caso interessante do ponto de vista tradutório: quando traduzi o poema pela primeira vez, abri mão de seguir a parte formal. Mas pelo fato de existir um ritmo que lembra os passos de um preso dentro de uma cela, que era um fator limitante da liberdade tanto quanto a dor que o poeta constantemente sentia, sendo esta última um tema central da poesia e da vida de Wat, a primeira versão não me satisfazia mais e resolvi retraduzir o poema. A tentativa de encontrar uma versão que fosse satisfatória durou cerca de cinco anos e, por fim, foi quebrada com ideias que surgiram durante uma aula sobre derrotas tradutórias, ilustrada justo pela primeira versão do poema. Temos nele, portanto, o testemunho do poeta preso entre as quatro paredes da sua dor e do tradutor que conseguiu se libertar das quatro paredes da impossibilidade de criar uma versão que fosse minimamente satisfatória.

\section{*** (w czterech ścianach mego bólu)}

Em minha dor emparedado sem janelas e sem portas. Ouço apenas indo e vindo o guarda atrás dos muros.

Os seus passos surdos, ocos 
medem a existência cega.

Noite ainda ou já a aurora?

Trevas em meus quatro muros.

Para que está indo e vindo?

Como vai me ceifar, se na cela da dor minha não há portas nem janelas?

Algures passam os anos da ardente sarça da vida. Aqui anda indo e vindo o guarda --- cão de face cega.

(Mentona, fevereiro de 1956)

Zbigniew Herbert (1924-1998) ${ }^{\mathrm{xix}}$ foi mais um dos gigantes da poesia polonesa do século XX. A edição da sua obra poética completa no Brasil está prevista para sair pela editora Âyiné e o poeta já é relativamente conhecido do público brasileiro. Mais um da geração dos Colombos, autor de uma poesia marcada pela ironia histórica, sobriedade e fidelidade aos ideais. Criador

46 do personagem Senhor Cogito, uma imagem do intelectual que enfrenta o tempo dos totalitarismos e consumismos, uma espécie de Dom Quixote, que não nega seu forte componente de Sancho Pança. O poema escolhido é o que abre o primeiro livro de Herbert, Struna światta (A corda de luz), de 1956, estreia tardia e marcada por lembranças da guerra e da morte da sua geração. Os seus protagonistas, assim como o Senhor Cogito, optam por se manterem fiéis ao amor e aos ideais humanos nos tempos de barbárie e indigência. E essa fidelidade à poesia, ao humano e ao ideal é a resposta poética de Herbert: é necessário escrever poesia depois de Auschwitz.

\section{Duas gotas (Dwie krople)}

Os bosques ardiam mas eles nos pescoços trançavam as mãos como buquês de rosas

as pessoas corriam para os abrigos ele dizia que a esposa tinha cabelos nos quais era possível se esconder

debaixo de um só cobertor sussurravam palavras despudoradas a ladainha dos enamorados 
Quando estava muito ruim

saltavam para dentro dos olhos em frente

e os fechavam com força

com tanta força que não sentiram o fogo

chegando às sobrancelhas

até o fim foram corajosos

até o fim foram fiéis

até o fim foram semelhantes

como duas gotas

paradas na borda do rosto

Wisława Szymborska (1923-2012) ${ }^{\mathrm{xx}}$ - por vezes chamada de "Mozart da poesia", é uma poeta que dispensa quiasquer apresentações, por já ser bem familiar ao público brasileiro. Prêmio Nobel de Literatura de 1996, foi autora de poemas que unem a simplicidade e a precisão com a profundidade da reflexão. O poema "Ainda", de mais uma representante da geração dos Colombos, foi publicado em 1957 e é mais um eco poético dos terríveis acontecimentos que perduram na memória e no ar, apesar do transcorrer do tempo. A memória do Holocausto e o trauma das testemunhas impotentes das atrocidades não foram bem trabalhados na Polônia nos tempos comunistas. $\mathrm{Na}$ verdade, esse processo, embora muito avançado, ainda está em curso. Tanto mais importante é então a voz da poeta refletindo sobre o tema bem antes de toda essa elaboração estar sendo feita.

\section{Ainda (Jeszcze)}

Nos selados vagões

pelo país os nomes vão,

mas aonde assim irão,

e se uma hora descerão,

não perguntem, não direi, não sei.

O nome Natan a parede esmurra, o nome Isaac canta em loucura, o nome Sara aos gritos água pede para o nome Aaron que morre de sede.

Não salte do trem que corre, nome de Davi.

Tu és um nome à derrota condenado nome sem casa, que a ninguém aqui se dá - para carregar, demais pesado.

Ao filho um nome eslavo vamos dar, pois aqui contam na cabeça os cabelos, 
pois por aqui separam o bem do mal pelos nomes e dos olhos o modelo.

Não salte do trem que corre. O filho será Lech.

Não salte do trem que corre. Ainda não é a hora.

Não salte. A noite ressoa como o riso

e imita o bater dos trilhos e das rodas.

Uma nuvem de gente ia sobre o país, muita nuvem, pouca chuva, uma lágrima, pouca chuva, uma lágrima, estiagem.

Para a floresta negra levam os carris.

Tá-aqui-tá-aqui, bate a roda. Pela floresta sem clareiras.

Tá-aqui-tá-aqui, o trem, transporte dos clamores, aligeira.

Tá-aqui-tá-aqui. Ainda ouço de noite acordada

tá-aqui-tá-aqui, do silêncio no silêncio a martelada.

Jerzy Ficowski (1924-2006) ${ }^{x x i}$ já é conhecido do leitor brasileiro, graças ao volume A leitura das cinzas, que é uma reflexão sobre a memória do Holocausto e foi publicado pela editora Âyiné, e a algumas publicações em revistas e jornais. O poeta, mais um representante da geração de Colombos, como todos aqueles que sobreviveram à guerra, não se ateve nas suas obras somente aos temas relacionados com ela. Embora o Holocausto e suas marcas sejam um dos temas de Ficowski, o autor que também foi pesquisador do folclore cigano e judaico, além de ter sido uma espécie de Max Brod de Bruno Schulz, foi um dos poetas poloneses em cuja obra a língua tem um papel fundamental. Mestre de neologismos (principalmente fraseológicos), falsas etimologias, trocadilhos e invenções sintáticas, Ficowski apresenta um desafio ímpar a qualquer tradutor. Abaixo um dos poemas que obrigam o tradutor a uma ginástica e mostram a face brincalhona do poeta, que também foi um autor importante de poesia infantil.

\section{Para o dia de São Nunca (Na Święty Nigdy)}

São Nunca apóstata dos calendários de rito algum em molduras emprestadas na auréola alheia que és levado para trás dos altares entre o afresco e a teia de aranha 
que sempre e em todo lugar

nos proteges

do Sempre Emtodolugar

bom e mau

a ti rogamos Nunca

rezes por nós

Anna Świrszczyńska $(1909-1984)^{\mathrm{xxii}}$ foi poeta, prosadora e autora de literatura infantil. Estreou em 1936 como poemas que deixam visível seu fascínio pelo idioma (principalmente estilizações arcaizantes), assim como o fascínio pelas artes plásticas, talvez herança do pai que foi pintor. Durante a guerra, Świrszczyńska participou como enfermeira do Levante de Varsóvia. Sua visão da guerra, da crueldade e horror, a visão da guerra do ponto de vista de uma mulher, encontrou sua expressão no livro Eu construía a barricada, publicado 30 anos depois do fim da guerra. Nesse período, a poeta já havia encontrado sua própria voz, diferente daquela de antes da guerra: sóbria, concisa, precisa e plástica. Havia encontrado também seu tema: como é ser mulher. O mundo observado do ponto de vista de uma mulher, seus sentimentos e seu corpo tornaram-se o assunto mais importante e revolucionário na sua poesia. O feminismo declarado de seus poemas foi taxado por vezes de exibicionista, mas a aproximação direta e econômica à sexualidade feminina, psiquismo da mulher, sua sensualidade e seus problemas são um dos principais valores de seu trabalho. O poema apresentado abaixo provém do livro publicado em 1970 e permite entender a extraordinária coragem e qualidade precursora da autora, que ainda espera o devido reconhecimento e presença no cânone da literatura polonesa.

\section{Coragem (Odwaga)}

Não serei escrava de nenhum amor.

A ninguém

entregarei o objetivo da minha vida, meu direito de crescer incessantemente até o último suspiro.

Atada pelo obscuro instinto da maternidade, ávida por ternura como um asmático por ar, com que labuta construo em mim meu belo e humano egoísmo, reservado há séculos para o homem.

Contra mim

estão todas as civilizações do mundo, 
todos os livros sagrados da humanidade

escritos pelos anjos místicos

com a loquaz pena do relâmpago.

Os dez Maomés

em dez línguas cobertas de requintada pátina

me ameaçam com a danação

na terra e no céu eterno.

Contra mim

está meu próprio coração.

Por milênios adestrado

na virtude cruel do sacrifício.

Miron Białoszewski (1922-1983) ${ }^{\mathrm{xxiii}}$ foi poeta, prosador e dramaturgo. Sua obra foi marcada pelo vanguardismo e interesse pelos limites do idioma. Por um lado explorador da língua falada, de seus erros, imprecisões e falhas, por outro, pesquisador dos limites da língua e dos jogos com a palavra, cujos automatismos e rotinas ele constantemente provocava. Mais um representante da geração dos Colombos, Białoszewski é autor da obra que desafiou as maneiras de lembrar sobre a história. Em Pamiętnik z Powstania Warszawskiego (Memórias do Levante

50 de Varsóvia) contrapôs a visão heroica às lembranças de um civil, vítima dos acontecimentos. O poema escolhido provém do livro Oho (Uhum), editado postumamente em 1986, e descreve o pesadelo de quem teve que conviver com os tempos do terror nazista e com o genocídio de compatriotas e vizinhos judeus. Além de uma pequena demonstração da escrita falada do poeta, vemos também uma tentativa de se aproveitar dos recursos gráficos de uma maneira inusitada, marcando a frase conclusiva do poema em negrito.

\section{*** (*** moja glowa była $\dot{Z} \mathbf{y d e m})$}

minha cabeça era um judeu andava de bonde, não se pode descer, alemães, só andar, andar, ah, pelo menos, não se mover, ora, é possível aham...o travesseiro aham...o despertar 


\section{É ruim ter um passado, mesmo que alheio}

Os próximos quatro poetas: Barańczak, Krynicki, Kornhauser e Zagajewski são representantes do movimento literário denominado de "Nowa Fala" (Nova Onda), às vezes chamado de geração de '68. Um dos elementos comuns dos poetas da geração foi a atenção dada à palavra oficial, a rebelião contra a palavra viciada das propagandas políticas, a "novilíngua" submetida à crítica e à transformação poética. A rebeldia contra o uso oficial da linguagem fez com que os poetas confrontassem a realidade e o idioma sujeitos à propaganda política, "denunciando a sua degradação e restituindo-lhe o poder de expressar uma complexa realidade social e existencial" (SIEWIERSKI, 2000, p. 191). Os quatro poemas aqui escolhidos de poetas que estrearam nesse movimento mostram caminhos poéticos diferentes, que evoluíram a partir daquele momento inicial.

Stanisław Barańczak (1946-2014) ${ }^{x x i v}$ foi poeta, ensaísta, cientista, ativista social e um dos maiores tradutores do século XX polonês. Perseguido pelo sistema comunista, optou por emigrar da Polônia em 1981 para trabalhar na eslavística da Universidade de Harvard, mas continuou participando ativamente da vida intelectual e política da Polônia. O poema apresentado aqui foi publicado em 1972 e de alguma maneira reflete os princípios de "Nova Onda" - mistura o banal com o inovador, por meio de uma construção preciosa, desnuda a incapacidade de lidar com a dor sem proteger-se dela com palavras. No hiato entre a construção poética e o grito de dor, nasce a reflexão, nasce o poema.

\section{Porque só este mundo da dor (Bo tylko ten świat bólu)}

Porque só este mundo da dor, só esta esfera achatada no torno de gelo, açoitada por tempestades, quebrada nas rodas dos meridianos, crepitando nas fronteiras grosseiramente suturadas, só esta fina pele da crosta terrestre, rachada com os rios, excretando o suor dos mares salgados entre os golpes de lava e os golpes do sol

porque só este mundo da dor, só este corpo no torno da terra e do ar, açoitado com as balas, quebrado no meio com o golpe de um punho, crepitando sob o cassetete nas suturas dos ossos do crânio, só esta fina crosta da pele humana, rachada sangrentamente, vertendo salgados mares de suor 
entre o golpe do nascimento e da morte

porque só este mundo da dor; porque só este mundo

é dor; porque o mundo é só esta dor.

Julian Kornhauser (1946-) ${ }^{\mathrm{xxv}}$ é um poeta, ensaísta, tradutor, crítico literário e cientista. Como outros membros de sua geração, sofreu perseguições do governo comunista e da censura, sendo seu livro proibido um dos primeiros samizdats (ou seja, livros produzidos e distribuídos ilegalmente) poloneses. De ascendência judaica por parte do pai e silesiana por parte da mãe, os temas do Holocausto e das minorias voltam frequentemente em sua poesia. O poema escolhido, publicado em 1985, é mais um dos que refletem sobre o Extermínio e relembram os mortos nas chamas do gueto, que vivem na memória dos que habitam o espaço de sua agonia, mesmo não tendo participado diretamente dos acontecimentos.

\section{A morte - Uma judia (Śmierć - Żydówka)}

Comiam fogo

engoliam seu próprio mundo

52 que ainda não tinha tido tempo de se manchar

do teto dava para ver os passantes

no lado ariano

alguns olhavam para cima

e apontavam algo com seus dedos

a morte como uma broa de pão

salvava da voz

do mundo

mas foi a morte - uma judia

estuprada pelos vlasovtsy

o bunquer no qual morreram

foi uma diminuta pílula de cianureto

que engolimos

não há mais o muro

nem o Umschlagplatz

nem o sangue que balançava

nem os olhos que viram

apenas

todo ano pulo da janela

da casa em chamas 
e não sei

o que gritam

e por que

Adam Zagajewski (1945-) $)^{x x i}$ é certamente o representante da geração com mais renome internacional. Poeta e ensaísta, por vezes, também tradutor. Como seus outros colegas, sofreu proibições de publicação na época do comunismo. Viveu os últimos anos do sistema na emigração em Paris. Depois da abertura, voltou a morar em Cracóvia, frequentemente trabalhando como professor visitante nas universidades estadunidenses. Sua poesia, ao mesmo tempo em que celebra epifanias e procura por beleza, prima pela busca de sentido. Aparece muitas vezes como candidato ao Prêmio Nobel de Literatura. O poema escolhido, publicado em 1990, reflete a experiência entre o cotidiano e a memória do genocídio, a memória que não é do eu lírico. Observamos o cotidiano de um viajante moderno que habita um espaço dissonante entre o mundo que não é dele e a memória da atrocidade. Nele, um aniversário de estranhos contrasta com as memórias da morte dos outros, colocando o protagonista no espaço entre os dois, entre a vida e a morte, a culpa e o afastamento dela.

\section{Assistindo ao "Shoah" num quarto de hotel na América (Oglądając "Shoah" w pokoju hotelowym, w Ameryce)}

A noite pode ser delicada como o pelo de um potro, mas nós preferimos jogar xadrez ou baralho: aqui os hóspedes do hotel cantavam happy birthday to you enquanto o televisor caolho embaralhava as imagens com indiferença.

As árvores da minha infância cruzaram o oceano

e me cumprimentavam secamente da tela.

Os camponeses poloneses envolviam-se nas disputas teológicas

com lábia jesuíta, só os judeus calavam, cansados da longa agonia.

Os riachos das minhas férias fluíam com prudência

pelo continente alheio, estranho a eles.

As carroças carregavam cabelos no lugar de feno

e seus eixos rangiam sob o peso fofo.

Somos inocentes, declaravam os pinheiros.

Os SS-es se transformaram em anciões frágeis, os médicos lutavam por seus corações, vidas, consciências.

Já estava tarde, sentia a ardilosa onda de sonolência.

Queria adormecer, adormecer, mas os hóspedes do hotel

gritavam cada vez mais alto happy birthday to you

(gritavam mais alto que os judeus morrendo).

Os grandes caminhões levavam as estrelas do firmamento, os trens melancolicamente andavam na chuva. 
Sou inocente, justificava-se Mozart, só o álamo tremedor tremia como sempre, confessando qualquer crime.

Onde está minha casa - cantavam os judeus tchecos.

Não existe casa, as casas ardem, nas casas assobia o gás frio.

Estava cada vez mais sonolento e inocente.

O televisor me assegurava: nós dois estamos acima de qualquer suspeita.

$\mathrm{O}$ aniversário tornava-se cada vez mais ruidoso.

Amontoados numa pirâmide que tocava o céu

os sapatos de Auschwitz queixavam-se silenciosamente:

infelizmente, sobrevivemos à humanidade.

Durmamos, durmamos, não temos para onde ir.

Ryszard Krynicki (1943-) ${ }^{\mathrm{xxvii}}$ é um dos mais importantes poetas da atualidade. Perseguido na época do comunismo, Krynicki também é tradutor e editor. A editora a5, fundada por ele e sua esposa, é, no momento, uma das mais importantes divulgadoras da poesia na Polônia. A poesia de Krynicki, econômica e precisa, é marcada por procuras éticas e místicas, palavras que provocam o silêncio. É curioso como alguns poemas parecem ter sido escritos bem recentemente - como este traduzido aqui, e publicado originalmente há quase quinze anos..

54 Poetas são profetas e hoje, na era da "pós-verdade", uma observação feita na época em que parecíamos ter esquecido por um momento do poder das distorções praticadas sob o nome "verdade", apenas ganha mais força.

\section{Verdade? (Prawda?)}

O que é a verdade?

Onde está sua sede?

Onde está sua diretoria?

Onde está seu conselho fiscal?

Onde estão seus advogados?

Onde estão seus guardas?

Onde está sua seção de lançamentos?

Onde está sua seção de marketing?

Qual é sua audiência?

Qual é sua força de penetração?

Qual patrocínio midiático?

Vende bem?

Já entrou na bolsa?

Quanto valem suas ações?

Jacek Kaczmarski (1957-2004) $)^{\text {xxviii }}$ foi conhecido como o bardo do "Solidariedade". Embora ainda haja (principalmente no mundo acadêmico) quem resista a chamá-lo de poeta polonês, 
em tempos de Prêmio Nobel para Bob Dylan e Prêmio Camões para Chico Buarque, não há mais dúvida de que ele deveria ser assim classificado. Um dos maiores "cantautores" na história da Polônia, mais um dos grandes autores poloneses de ascendência judaica, Kaczmarski teve uma vida atribulada, frenética e paradoxal, tanto como ídolo de massas na Polônia — quando nem estava presente no país, já que passou a última década do comunismo no exílio na Europa Ocidental - quanto depois da queda do sistema, quando desgostoso pelos rumos que a vida no país livre estava tomando e incomodado pela máscara de bardo nacional, decidiu emigrar novamente, dessa vez para a Austrália. Logo depois da decisão de retornar daquele país para a Polônia, iniciou mais uma luta, dessa vez contra a doença, contra a qual acabou perdendo. A obra de Kaczmarski, por vezes chamado de Cassandra, é marcada por profundas análises historiosóficas, uma erudição descomunal e diálogos com os mestres da cultura polonesa e mundial. O poema escolhido é um dos últimos do autor e foi escrito um ano e duas semanas antes de sua morte, quando Kaczmarski, já sem poder cantar, pressentia que a luta contra o câncer tinha poucas chances de êxito. Temos aqui um poeta praticando a clássica figura poética da ars moriendi.

\section{Túnel (Tunel)}

O que senti, me perguntam, quando por um triz, deitado, a relva do paraíso eu quase curti,

ou, considerando a opção menos otimista, no caldeirão fervendo eu seria um banhista;

então - no início ainda existia a fresta, pela qual via a mesa, o vinho e pão na cesta

ouvia o louro gritando e o cão ganindo sem a menor ideia se - me chamando ou carpindo?

Esta partida - deitado e apesar da vontade da zona de luz para a de incolor obscuridade,

mesmo que indolor, não era prazerosa, mas ruim, pois não ocorria comigo, mas só dentro de mim,

como se para dentro de mim olhasse e ficasse nauseado pela vista do cume abissal, enorme e vago.

Pensei: este deve ser o tal do túnel de luz, que para a vida eterna - se é que conduz - conduz, 
e senti grande alívio, que, enfim, está tudo acabado e que em breve saberia o que há do outro lado...

Só que por lá não havia nenhuma luminosidade, era mais um vapor sujo, como no esgoto da cidade

era mais para a calada que desperta a suspeita, o silêncio falso, que todo enganado espreita,

já na sombra da forca, sabendo da sentença, de todo inconsciente...de que está em suspenso!

Sem poder afirmar se era o céu ou o inferno, enfim literal e metaforicamente - cheguei então em mim.

No ganir do cão, no berro do louro - compreendi que só consigo achar sombras e fulgores por aqui,

que só aqui, da perspectiva onde o pão e o vinho viso, pode-se temer o abismo e almejar o paraíso

por aqui tudo que é lindo, tudo que é terrível,

56 pois vive - e é vivido por tudo que está - vivo...

Osowa 27.03.2003

Tomasz Różycki (1970-) $)^{x x i x}$ é um dos mais interessantes poetas poloneses da contemporaneidade, laureado com vários prêmios literários e traduzido para vários idiomas. Seus poemas, ao mesmo tempo em que resgatam a forma poética e se enraízam na tradição literária, refletem sobre os problemas sempiternos e o mundo moderno. O poema escolhido provém do livro Kolonie (As colônias), de 2005.

\section{Café e tabaco (Kawa i tytoń)}

Ao começar a escrever ainda não sabia o que fariam de mim os poemas, que eu me tornaria um estranho espectro, sempre mal dormido, de pele transparente, na urbe perdido,

vagando, como um cara um pouco drogado, indo dormir apenas na ira da alvorada, de madrugada os amigos visitando, medonho, duro, como um piolho, inseto do sonho,

por um naco de pele atraído ou por um suspiro. Em que me converteriam, ainda não sabia, 
esses poemas bobos, meu bem, e nem que quem vai me trazer pra vida é justo você,

que graças a você serei visível, com você vou deitar e o instante em que seu sono vem vou esperar.

Krystyna Dąbrowska (1979-) ${ }^{\mathrm{xxx}}$ é poeta e tradutora. Seus poemas, concisos e simples, apresentam um olhar original sobre o mundo (aliás, a observação do mundo seja pelos olhos da viajante, seja olhando pela janela de casa é um de seus grandes temas). A primeira laureada com o prêmio Wisława Szymborska de poesia (2013), de alguma maneira continua a tradição szymborskiana: poemas precisos, que refletem sobre o mundo unindo as descrições da realidade à profundidade da reflexão. $\mathrm{O}$ poema escolhido provém de seu primeiro livro publicado em 2006.

\section{A agência de viagens (Biuro podróży)}

Sou uma agência de viagens para os mortos organizo para eles voos para os sonhos dos vivos.

Vêm até mim personalidades famosas, como Heráclito, para visitar um escritor apaixonado por ele,

mas também mortos não conhecidos amplamente - como um agricultor da aldeia Wasiły, que quer aconselhar sua mulher a respeito da criação de coelhos.

Âs vezes uma família de muitas gerações aluga um avião

e pousa na testa do último descendente,

lido também com os assassinados,

que, cursando frequentemente os sonhos dos sobreviventes,

juntam pontos no programa frequent flyer.

Não nego meus serviços a ninguém.

Encontro os melhores roteiros

e me culpo quando um jovem rapaz,

para chegar ao sonho da sua namorada,

precisa voar com uma conexão no sonho de uma dona que ronca.

Ou quando as condições do tempo provocam um pouso de emergência

e o morto liga: faça algo,

fiquei preso no sonho de uma criança apavorada!

Acidentes assim são um estresse e um desafio para mim, uma pequena agência com grandes ambições -

pois embora não tenha ingresso nem para o mundo dos mortos e

nem para os sonhos alheios,

é graças a mim que eles se encontram. 


\section{REFERÊNCIAS}

Aproximações: Europa do Leste em Língua Portuguesa, Brasília: Lisboa, No. 1-4, 19871990.

ASCHER, Nelson. Poesia alheia. 124 poemas traduzidos. Org. e trad. Nelson Ascher. Rio de Janeiro: Imago, 1998.

CIESZYŃSKA, B.; DA SILVA F.M.; KALEWSKA A.; DAL FARRA, M.L.; BOROWSKI, G. (org.) Diálogos no feminino. Antologia Poética Maria Pawlikowska-JasnorzewskaFlorbela Espanca. Lisboa- Varsóvia, 2017.

DREWNO, Agnieszka (org.). Tuwim. Varsóvia: Babel Studio, 2013.

FERRAZ, EUCANAÃ. A poeta e a pedra. (trad. de Henryk Siewierski). Revista Piauí, Edição 66, março de 2012. Disponível em: https://piaui.folha.uol.com.br/materia/a-poeta-e-a-pedra/, acesso em: 26.07.2019.

FICOWSKI, Jerzy. A leitura das cinzas. Tradução e organização Piotr Kilanowski. Belo Horizonte-Veneza: Âyiné, 2018.

FLORES, Guilherme Gontijo. Tomasz Różycki por Rob Packer e Piotr Kilanowski. Blogue Escamandro. Disponível em: https://escamandro.wordpress.com/2019/03/05/tomasz-rozyckipor-rob-packer-e-piotr-kilanowski/, acesso em: 18.07.2019.

HERBERT, Zbigniew. A fidelidade das coisas. Revista Piauí, vol. 20, São Paulo, 2008, disponível em: https://piaui.folha.uol.com.br/materia/a-fidelidade-das-coisas/, acesso em: 26.07.2019.

HERBERT, Zbigniew. A viagem do Senhor Cogito/Podróż Pana Cogito. Seleção e organização Danuta Opacka-Walasek e Piotr Kilanowski. Tradução de Piotr Kilanowski. Katowice: Gnome, 2016.

HERBERT, Zbigniew. Escolhido pelas estrelas. tradução de inglês de José Sousa Braga. Lisboa: Assírio \& Alvim, 2009.

HERBERT Zbigniew. O Senhor Cogito. Anotações da casa morta. São Paulo: Demônio Negro, 2019.

HERBERT, Zbigniew. Um bárbaro no jardim. Trad. De Henryk Siewierski. Belo Horizonte: Âyiné, 2018.

JOVANOVIĆ, Aleksandar. Céu vazio. 63 poetas eslavos. Org., est. intr., notas e trad. Aleksandar Jovanović. São Paulo: Hucitec, 1996.

KEMPINSKA, Olga D. Guerizoli. A amante do piloto. (n.t.) Revista Literária em Tradução. Vol 1. Florianópolis, 2010, p. 98-126.

KEMPINSKA, Olga. Anna Świrszczyńska. O homem e a centopeia/Człowiek i stonoga. (n.t.). Revista Literária em Tradução, vol. 10, Florianópolis, 2015, p. 25-47). 
KILANOWSKI, Piotr. Ao ritmo do ósseo cascalhar das castanholas. Krystyna Dąbrowska e uma poesia atenta às fronteiras móveis entre nós e o mundo. Suplemento Pernambuco, vol. 166, Recife, 2019 c. Disponível em:

https://www.suplementopernambuco.com.br/edi\%C3\%A7\%C3\%B5es-anteriores/78traducao/2403-krystyna-d\%C4\%85browska-e-uma-poesia-atenta-\%C3\%A0s-fronteiras-entren\%C3\%B3s-e-o-mundo.html, acesso em 10.12.2019.

KILANOWSKI, Piotr. As barricadas de Anna Świrszczyńska. Suplemento Pernambuco, vol. 137, Recife, 2017a. Disponível em:

https://www.suplementopernambuco.com.br/in\%C3\%A9ditos/1900-as-barricadas-de-anna\%C5\%9Bwirszczy\%C5\%84ska.html, acesso em: 26.07.2019.

KILANOWSKI, Piotr. Carta a Marc Chagall de Jerzy Ficowski. Suplemento Pernambuco, vol. 131, Recife, 2017b, p. 19-21. Disponível em:

https://www.suplementopernambuco.com.br/in\%C3\%A9ditos/1769-carta-a-marc-chagall,-dejerzy-ficowski.html, acesso em 26.07.2019

KILANOWSKI, Piotr. Notas sobre Anna Świrszczyńska e a poesia contra os mitos. Qorpus, vol. 25, Florianópolis, 2017c, disponível em: http://qorpus.paginas.ufsc.br/como-e/edicao-n25/notas-sobre-anna-swirszczynska-e-a-poesia-contra-os-mitos-piotr-kilanowski/, acesso em: 17.07.2019.

KILANOWSKI, Piotr. Poemas de Aleksander Wat. Qorpus. vol. 24 Florianópolis, 2017d, disponível em: http://qorpus.paginas.ufsc.br/teatro-na-praia/edicao-n-024/poemas-dealeksander-wat-traducao-de-piotr-kilanowski/, acesso em: 18.07.2019.

KILANOWSKI, Piotr. Poemas de Jerzy Ficowski do livro Odczytanie popiołów (A leitura das cinzas), Qorpus,vol. 17, Florianópolis, 2015a. Disponível em:

http://qorpus.paginas.ufsc.br/teatro-na-praia/edicao-n-017/poemas-de-jerzy-ficowski-do-livroodczytanie-popiolowa-leitura-das-cinzas-traducoes-de-piotr-kilanowski/, acesso em: 17.07.2019.

KILANOWSKI, Piotr. Poemas de Wisława Szymborska. Qorpus,v.15, Florianópolis, 2014, disponível em: http://qorpus.paginas.ufsc.br/teatro-na-praia/edicao-n-015/poemas-dewislawa-szymborska-traducao-de-piotr-kilanowski/, acesso em: 26.07.2019.

KILANOWSKI, Piotr. Poemas de Zbigniew Herbert, Qorpus, vol.24, Florianópolis, 2017e, disponível em: http://qorpus.paginas.ufsc.br/teatro-na-praia/edicao-n-024/poemas-dezbigniew-herbert-traducoes-de-piotr-kilanowski/, acesso em: 26.07. 2019.

KILANOWSKI, Piotr. Poesias de Zbigniew Herbert. Qorpus, vol. 19, Florianópolis, 2015 b. disponível em: http://qorpus.paginas.ufsc.br/teatro-na-praia/edicao-n-19/4045-2/, acesso em: 26.07.2019

KILANOWSKI, Piotr. Queria permanecer fiel à clareza incerta- sobre a poesia de Zbigniew Herbert. Tese (doutorado) - Universidade Federal de Santa Catarina, Centro de Comunicação e Expressão, Programa de Pós-Graduação em Literatura, Florianópolis, 2018a. 
KILANOWSKI, Piotr. Sobre Jan Kochanowski, o "pai" do idioma polonês. Suplemento Pernambuco, vol. 161, p. 24-27, Recife, 2019a. Disponível em:

http://www.suplementopernambuco.com.br/in\%C3\%A9ditos/2314-sobre-jan-kochanowski,o-pai-do-idioma-polon\%C3\%AAs.html, acesso em: 26.07.2019.

KILANOWSKI, Piotr. Três poemas de Czesław Miłosz. Qorpus, vol.16, Florianópolis, 2015c), disponível em: http://qorpus.paginas.ufsc.br/teatro-na-praia/edicao-n-016/trespoemas-de-czeslaw-milosz-traducao-de-piotr-kilanowski/, acesso em: 26.07.2019.

KILANOWSKI, Piotr. Władysław Szlengel, Poeta do Gueto de Varsóvia. Suplemento Pernambuco. Vol.146, Recife, 2018b, p. 24-27.

KILANOWSKI, Piotr. Zbigniew Herbert: uma apresentação e cinco poemas. Suplemento Pernambuco. Recife, 2019b, disponível em:

https://www.suplementopernambuco.com.br/in\%C3\%A9ditos/2260-zbigniew-herbert-umaapresenta\%C3\%A7\%C3\%A3o-e-cinco-poemas.html, acesso em: 26.07.2019.

ŁYCHOWSKI, Tomasz. Poesia da Polônia: Ewa Lipska, Ryszard Krynicki. Revista Brasileira, vol. 89, Rio de Janeiro, 2016.

MENDONÇA, Vanderley (org.). Lira argenta. São Paulo: Demônio Negro, 2017.

60 MICKIEWICZ, Adam. Adam Mickiewicz: um poeta peregrino. Poemas selecionados traduzidos por Mariano Kawka, Machado de Assis, Marcelo Paiva de Souza, José Santiago Naud. Org. por Henryk Siewierski. Brasília: Oficina Editorial do Instituto de Letras, UnB, 1998.

MIŁOSZ, Czesław. Não mais. Trad. e org. Henryk Siewierski e Marcelo Paiva de Souza. Brasília: Editora UnB, 2003.

MIŁOSZ, Czesław. O testemunho da poesia: seis conferências sobre as aflições de nosso século. Trad. Marcelo Paiva de Souza, Curitiba: Editora UFPR, 2012.

MIŁOSZ, Czesław, RÓŻEWICZ, Tadeusz, SZYMBORSKA, Wisława, HERBERT, Zbigniew (1994) Quatro poetas poloneses. Tradução e prefácio Henryk Siewierski e José Santiago Naud. Curitiba: Secretaria do Estado da Cultura.

MIŁOSZ, Czesław, RÓŻEWICZ, Tadeusz, SZYMBORSKA, Wisława, KRYNICKI, Ryszard, HERBERT, Zbigniew. Versos polacos. Tradução de Maria Teresa Bação Fernandes, Filipa Menezes, Maria Clara Correia, Carlos Santos Pereira, Henryk Siewierski. Lisboa: Faculdade de Letras, 1985,

NORWID, Cyprian. O Piano de Chopin. Trad. de Marcelo Paiva de Souza e Henryk Siewierski. Brasília: Universidade de Brasília, 1994.

NUTO, João Vianney Cavalcanti, SIEWIERSKI, Henryk. Opção pelas aproximações. Tradução em Revista, vol. 10, Rio de Janeiro, 2011. (Disponível em https://www.maxwell.vrac.puc-rio.br/17851/17851.PDFXXvmi=, acesso em 18.07.2019). 
PRZYBYCIEN, Regina. Wisława Szymborska. 5 poemas. Oroboro, vol.4, Curitiba, 2005.

SIEWIERSKI, Henryk. História da literatura polonesa. Brasília: EdUnB, 2000

SIEWIERSKI, Henryk e SOUZA, Marcelo Paiva de. A moderna poesia da Polônia (antologia). Poesia Sempre, v. 30, Rio de Janeiro, 2009, p. 31-92.

SOUZA, Marcelo Paiva de. Cyprian Kamil Norwid/Bolesław Leśmian: estranha beleza (apresentação, poemas e notas). Revista Brasileira, vol. 78, Rio de Janeiro, 2014.

SOUZA, Marcelo Paiva de. Tadeusz Różewicz: fazer poesia depois de Oświęcim. Contexto. n. 36, Vitória, 2019, p. 239-268.

SOUZA, Marcelo Paiva de. "Uma descarada janela judia": Władysław Szlengel, cronista do Gueto de Varsóvia. In: XIV Congresso Internacional Abralic, 2016, Belém. Anais - XIV Congresso Internacional Abralic. Belém: Abralic, 2016. v. 1. p. 1-11.

SZLENGEL, Władysław. A janela para o outro lado. Poemas do gueto de Varsóvia. Organização, tradução e notas de Piotr Kilanowski. Fortaleza: Dybbuk, 2018.

SZYMBORSKA, Wisława; MıŁOSZ, Czesław. Alguns gostam de poesia. Seleção, introdução e tradução de Elżbieta Milewska e Sérgio das Neves. Lisboa: Cavalo de Ferro, 2004.

SZYMBORSKA, Wisława. Amor feliz. Seleção, tradução e prefácio de Regina Przybycien. São Paulo: Companhia das Letras, 2016.

SZYMBORSKA, Wisława. Paisagem com grão de areia. Trad. de Júlio Souza Gomes. Lisboa: Relógio d'Água, 1998.

SZYMBORSKA, Wisława. Instante. Tradução de Elżbieta Milewska e Sérgio das Neves. Lisboa: Relógio d'Água, 2006.

SZYMBORSKA, Wisława. O poeta e o mundo. Revista Piauí, Edição 8, maio de 2007. Disponível em: https://piaui.folha.uol.com.br/materia/o-poeta-e-o-mundo/, acesso em: 26.07.1019.

SZYMBORSKA, Wisława. Poemas. Seleção, tradução e prefácio de Regina Przybycien. São Paulo: Companhia das Letras, 2011.

SZYMBORSKA, Wisława. Riminhas para as crianças grandes. Trad. e org. Piotr Kilanowski e Eneida Favre. Belo Horizonte: Âyiné, 2018.

SZYMBORSKA, Wisława. Um passo da arte eterna. Tradução, concepção, seleção e posfácio de Teresa Fernandes Swiatkiewicz, prefácio de Beata Elżbieta Cieszyńska. Lisboa: Esfera do Caos, 2013.

ŚWIRSZCZYŃSKA, Anna. Eu construía a barricada. Tradução, organização e introdução de Piotr Kilanowski. Curitiba: Dybbuk, 2017. 
i* Piotr KILANOWSKI - Graduado em Filologia hispânica com especialização em inglês (1990-93) pela Universidade de Adam Mickiewicz, Polônia. Graduado em Letras (1995) e Mestre em Literatura (1997) pela Universidade de Brasília. Doutor em Literatura (2018) pela Universidade Federal de Santa Catarina. Professor adjunto 3 na Universidade Federal do Paraná. Universidade Federal do Paraná, Setor de Ciências Humanas, Departamento de Polonês, Alemão e Letras Clássicas. Curitiba, Paraná, Brasil.

Currículo acadêmico: http://lattes.cnpq.br/3745945919610032

ORCID: https://orcid.org/0000-0003-0803-4291

E-mail: emaildopiotr@gmail.com

ii Existe um livro com traduções de poemas de Mickiewicz, que inicia a história da sua recepção no Brasil com Castro Alves e Machado de Assis fazendo traduções indiretas de seus poemas: MICKIEWICZ, Adam. Adam Mickiewicz: um poeta peregrino. Poemas selecionados traduzidos por Mariano Kawka, Machado de Assis, Marcelo Paiva de Souza, José Santiago Naud. Org. por Henryk Siewierski. Brasília: Oficina Editorial do Instituto de Letras, UnB, 1998.

iii Há uma edição de um poema de Norwid em livro: NORWID, Cyprian. O Piano de Chopin. Trad. de Marcelo Paiva de Souza e Henryk Siewierski. Brasília: Universidade de Brasília, 1994, além de alguns de seus poemas traduzidos por Marcelo Paiva de Souza (SOUZA, 2014, p. 306-311).

iv Por ocasião de "Ano Tuwim" foi publicado um livreto que nos apresenta a vida e a obra do poeta, falando das suas ligações com o Brasil. O livro contou com a tradução de vários poemas seus. Os tradutores foram: Henryk Siewierski, Marcelo Paiva de Souza, Carlos Drummond de Andrade, Geir Campos, Aleksandar Jovanović, José Carlos Costa Dias, Geraldo Beltrán e André de la Cruz. DREWNO, Agnieszka (org.). Tuwim. Varsóvia: Babel Studio, 2013.

v Numa brochura publicada pela Faculdade de Letras em Lisboa: MIŁOSZ, Czesław, RÓŻEWICZ, Tadeusz, SZYMBORSKA, Wisława, KRYNICKI, Ryszard, HERBERT, Zbigniew. Versos polacos. Tradução de Maria Teresa Bação Fernandes, Filipa Menezes, Maria Clara Correia, Carlos Santos Pereira, Henryk Siewierski. Lisboa: Faculdade de Letras, 1985, Daqui por diante, outras menções às traduções dos poetas contidas nessa publicação serão referidas utilizando-se apenas o título da brochura.

vi Aproximações: Europa do Leste em Língua Portuguesa, Brasília: Lisboa, No. 1-4, 1987-1990. Uma vez que a relação das traduções poéticas publicadas na revista está disponível no anexo à entrevista: NUTO, João Vianney Cavalcanti, SIEWIERSKI, Henryk. Opção pelas aproximações. Tradução em Revista, vol. 10, Rio de Janeiro, 2011. (Disponível em: https://www.maxwell.vrac.puc-rio.br/17851/17851.PDFXXvmi=, acesso em: 18.07.2019), daqui por diante, outras menções às traduções dos poetas contidas nessa publicação serão referidas utilizando-se apenas o título da Revista.

vii MIŁOSZ, Czesław, RÓŻEWICZ, Tadeusz, SZYMBORSKA, Wisława, HERBERT, Zbigniew (1994) Quatro poetas poloneses. Tradução e prefácio Henryk Siewierski e José Santiago Naud. Curitiba: Secretaria do Estado da Cultura. Daqui por diante, outras menções às traduções dos poetas contidas nessa publicação serão referidas utilizando-se apenas o título do livro.

viii SIEWIERSKI, Henryk e SOUZA, Marcelo Paiva de. A moderna poesia da Polônia (antologia). Poesia Sempre, v. 30, Rio de Janeiro, 2009, p. 31-92. A antologia apresentava poemas de Aleksander Wat, Czesław Miłosz, Tadeusz Różewicz, Tymoteusz Karpowicz, Miron Białoszewski, Wisława Szymborska, Zbigniew Herbert, Stanisław Grochowiak, Adam Zagajewski e Stanisław Barańczak, em traduções de Marcelo Paiva de Souza, Henryk Siewierski, José Santiago Naud, Zbigniew Wódkowski, Aleksandar Jovanović, Nelson Ascher, Ana Cristina César e Grażyna Drabik, Regina Przybycień e Fernando Mendes Viana. A maioria dos poemas já havia sido publicada antes em livros ou na revista Aproximações, mas houve também traduções inéditas nessa seleta. Daqui por diante, outras menções às traduções dos poetas contidas nessa publicação serão referidas utilizando-se apenas o título da antologia.

${ }^{\text {ix }}$ De sua autoria, além dos Lamentos, que estou traduzindo e publicando aos pouquinhos (KILANOWSKI, 2019a, foi por lá que o poema aqui apresentado teve sua estreia), temos em português apenas quatro poemas. Três deles na tradução de Aleksandar Jovanović (JOVANOVIĆ, 1996, p. 47-49) e um traduzido por Henryk Siewierski e Marcelo Paiva de Souza (SIEWIERSKI, 2000, p.35). Há também um pequeno trecho da peça A dispensa dos emissários gregos traduzido por Marcelo Paiva de Souza em MIŁOSZ, 2012, p. 96).

${ }^{x}$ Da sua extensa obra, traduzida para muitos idiomas, em português, até agora, só conhecemos a fábula Leão humilde, traduzida por Henryk Siewierski (SIEWIERSKI, 2000, p.68).

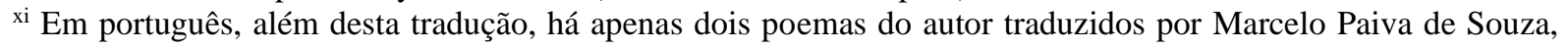
publicados na Revista Brasileira (SOUZA, 2014, p. 312-315).

xii Uma antologia da poeta foi traduzida para o português por Olga Guerizoli Kempinska: KEMPINSKA, 2010, p. 98-126). Dispomos também de uma seleta de traduções da autora para o português de Portugal, no livro que une seus poemas com os de Florbella Espanca: CIESZYŃSKA, B.; DA SILVA F.M.; KALEWSKA A.; DAL FARRA, 
M.L.; BOROWSKI, G. (org.) Diálogos no feminino. Antologia Poética Maria Pawlikowska-Jasnorzewska Florbela Espanca. Lisboa- Varsóvia, 2017.

xiii De acordo com meus conhecimentos esta é a primeira publicação da poeta em português.

${ }^{\text {xiv }}$ Em português dispomos de um livro de Szlengel traduzido e organizado por mim, que junta uma seleção de seus poemas com ensaios críticos sobre o poeta (SZLENGEL, 2018). Alguns poemas do livro foram reproduzidos no blogue Escamandro: https://escamandro.wordpress.com/2019/03/22/wladyslaw-szlengel-1912-1943-por-piotrkilanowski/, acesso em: 17.07.2019 e na revista Suplemento Pernambuco: (KILANOWSKI, 2018, p. 24-27), há também tradução do poema "Rzeczy" (Coisas) de autoria de Marcelo Paiva de Souza, que pode ser encontrada em um dos capítulos do livro acima referido e foi originalmente publicada em SOUZA, 2016).

${ }^{x v}$ Ao lado de Wisława Szymborska, Miłosz é o poeta polonês mais conhecido no Brasil. Além da sua prosa ficcional (apenas em traduções indiretas: MIŁOSZ, Czesław. A tomada do poder. Trad. do inglês Waltensir Dutra, Rio de Janeiro: Nova Fronteira, 1988; MIŁOSZ, Czesław. O vale do Issa. Trad. do inglês de Sonia Yumi Hirae, São Paulo: Novo Século, 2012 e a tradução anterior do mesmo livro: MIŁOSZ, Czesław. O vale dos demônios. Trad. do inglês de João Guilherme Linke, Rio de Janeiro: Francisco Alves, 1982), foram traduzidos alguns de seus ensaios (MIŁOSZ, Czesław. A mente cativa. Trad. do inglês de Dante Nery. São Paulo: Novo Século, 2010; MIŁOSZ, Czesław. O testemunho da poesia: seis conferências sobre as aflições de nosso século. Trad. Marcelo Paiva de Souza, Curitiba: Editora UFPR, 2012). Além de uma antologia poética traduzida por Henryk Siewierski e Marcelo Paiva de Souza (MIŁOSZ, Czesław. Não mais. Trad. e org. H. Siewierski e M. Paiva de Souza. Brasília: Editora UnB, 2003), seus poemas foram traduzidos por Aleksandar Jovanović (JOVANOVIĆ, 1996, p.83-86 e Nelson Ascher (ASCHER, 1998, p. 336-347), e foram publicados em Aproximações e incluídos nas antologias Quatro poetas poloneses, Versos polacos e na revista Poesia Sempre. O poema aqui apresentado foi publicado na revista Qorpus (KILANOWSKI, 2015c), e republicado na antologia Lira Argenta (MENDONÇA (org.), 2017, p.335-339. Além de romances e ensaios publicados em Portugal, há também uma antologia de Miłosz e Szymborska: SZYMBORSKA, Wisława; MIŁOSZ, Czesław. Alguns gostam de poesia. Seleção, introdução e tradução de Elżbieta Milewska e Sérgio das Neves. Lisboa: Cavalo de Ferro, 2004.

${ }^{\text {xvi }}$ De acordo com meus conhecimentos esta é a primeira publicação do poeta em português.

xvii Seus poemas em português foram publicados em Aproximações e incluídos em antologias Quatro poetas poloneses, Versos polacos e na da revista Poesia Sempre, além de serem traduzidos por Aleksandar Jovanović (JOVANOVIĆ, 1996, p. 105-108). Há um poema traduzido por Marcelo Paiva de Souza (em MIŁOSZ, 2012, p. 116), que recentemente publicou também mais quatro poemas traduzidos do autor (SOUZA, 2019)

xviii Atá agora seus poemas foram publicados em revista Aproximações, na antologia da revista Poesia sempre (traduções de Zbigniew Wódkowski e de Marcelo Paiva de Souza), e na revista Qorpus (KILANOWSKI, 2017d). ${ }^{\text {xix }}$ Há dois livros de poesias de Herbert traduzidos por mim para o português brasileiro (HERBERT, Zbigniew. A viagem do Senhor Cogito/ Podróż Pana Cogito. Seleção e organização Danuta Opacka-Walasek e Piotr Kilanowski. Tradução de Piotr Kilanowski. Katowice: Gnome, 2016 e HERBERT Zbigniew. O Senhor Cogito. Anotações da casa morta. São Paulo: Demônio Negro, 2019) e um traduzido indiretamente para o português lusitano (HERBERT, Zbigniew. Escolhido pelas estrelas. Tradução do inglês de José Sousa Braga. Lisboa: Assírio \& Alvim, 2009). Há também um livro de ensaios seus (HERBERT, Zbigniew. Um bárbaro no jardim. Trad. de Henryk Siewierski. Belo Horizonte: Âyiné, 2018). Seus poemas em português foram publicados em Aproximações e incluídos nas antologias Quatro poetas poloneses, Versos polacos e na da revista Poesia Sempre, além de serem traduzidos por Aleksandar Jovanović (JOVANOVIĆ, 1996, p.139-141), Nelson Ascher (ASCHER, 1998, p.351352), foram publicados com tradução minha na antologia Lira argenta (MENDONÇA (org.), 2017, p. 346-359). Há também uma longa lista de traduções de Herbert em revistas, jornais e blogues, disponível na íntegra na bibliografia da minha tese de doutoramento (KILANOWSKI, 2018a p. 471-473), cujo anexo contém a tradução da obra poética completa de Herbert. Mencionemos algumas das traduções esparsas: HERBERT, Zbigniew. A fidelidade das coisas. Revista Piauí, vol. 20, São Paulo, 2008, disponível em: https://piaui.folha.uol.com.br/materia/a-fidelidade-das-coisas/, acesso em: 26.07.2019; KILANOWSKI, Piotr. Poesias de Zbigniew Herbert. Qorpus, vol. 19, Florianópolis, 2015. disponível em: http://qorpus.paginas.ufsc.br/teatro-na-praia/edicao-n-19/4045-2/, acesso em 26.07.2019; KILANOWSKI, Piotr. Poemas de Zbigniew Herbert, Qorpus, vol.24, Florianópolis, 2017, disponível em: http://qorpus.paginas.ufsc.br/teatro-na-praia/edicao-n-024/poemas-de-zbigniew-herbert-traducoes-de-piotrkilanowski/, acesso em: 26.07. 2019; KILANOWSKI, Piotr. Zbigniew Herbert: uma apresentação e cinco poemas. Suplemento Pernambuco. Recife, 2019, disponível em: https://www.suplementopernambuco.com.br/in\%C3\%A9ditos/2260-zbigniew-herbert-umaapresenta\%C3\%A7\%C3\%A3o-e-cinco-poemas.html, acesso em: 26.07.2019. O poeta foi traduzido, entre outros, por Ana Cristina César e Grażyna Drabik, Carlitos Azevedo e Olga Kempinski, Sylvio Fraga Neto e Danuta Haczynska da Nóbrega, Paulo Henriques Britto, Marcelo Paiva de Souza e também pelo poeta português Herberto Helder. O poema aqui apresentado foi publicado na antologia A viagem do Senhor Cogito, referida detalhadamente acima, p. 23.

KILANOWSKI, Piotr. Vinte e dois poetas poloneses: uma pequena antologia de poesia em tradução. Belas Infiéis, Brasília, v. 9, n. 2, p. 31-64, 2020. 
xx Sem dúvida, é a mais conhecida entre os poetas poloneses, com quatro livros de poesia publicados em Portugal (SZYMBORSKA, Wisława; MIŁOSZ, Czesław. Alguns gostam de poesia. Seleção, introdução e tradução de Elżbieta Milewska e Sérgio das Neves. Lisboa: Cavalo de Ferro, 2004; SZYMBORSKA, Wisława. Instante. Tradução de Elżbieta Milewska e Sérgio das Neves. Lisboa: Relógio d'Água, 2006; SZYMBORSKA, Wisława. Paisagem com grão de areia. Trad. de Júlio Souza Gomes. Lisboa: Relógio d'Água, 1998); SZYMBORSKA, Wisława. Um passo da arte eterna. Tradução, concepção, seleção e posfácio de Teresa Fernandes Swiatkiewicz, prefácio de Beata Elżbieta Cieszyńska. Lisboa: Esfera do Caos, 2013) e três no Brasil (SZYMBORSKA, Wisława. Amor feliz. Seleção, tradução e prefácio de Regina Przybycien. São Paulo: Companhia das Letras, 2016; SZYMBORSKA, Wisława. Poemas. Seleção, tradução e prefácio de Regina Przybycien. São Paulo: Companhia das Letras, 2011; SZYMBORSKA, Wisława. Riminhas para as crianças grandes. Trad. e org. Piotr Kilanowski e Eneida Favre. Belo Horizonte: Âyiné, 2018). Seus poemas em português foram publicados em Aproximações e incluídos nas antologias Quatro poetas poloneses, Versos polacos, e na da revista Poesia Sempre. Foram traduzidos por Aleksandar Jovanović (JOVANOVIĆ, 1996, p.130-131), Nelson Ascher (ASCHER, 1998, p. 349350) e contaram com numerosas traduções publicadas em revista. Mencionemos algumas: PRZYBYCIEN, Regina. Wisława Szymborska. 5 poemas. Oroboro, vol.4, Curitiba, 2005. SZYMBORSKA, Wisława. O poeta e o mundo. Revista Piauí, Edição 8, maio de 2007. Disponível em: https://piaui.folha.uol.com.br/materia/o-poeta-eo-mundo/, acesso em: 26.07.1019. FERRAZ, EUCANAÃ. A poeta e a pedra. (trad. de Henryk Siewierski). Revista Piauí, Edição 66, março de 2012. Disponível em: https://piaui.folha.uol.com.br/materia/a-poeta-e-a-pedra/, acesso em: 26.07.2019. Primeiramente traduzida no Brasil pela dupla Ana Cristina César e Grażyna Drabik, (publicação na revista Religião e sociedade, vol.11, Rio de Janeiro, 1984), Szymborska, graças ao esforço de divulgação de, entre outros, Regina Przybycień e Henryk Siewierski, está entre os poetas estrangeiros mais lidos no Brasil. O poema aqui apresentado foi publicado primeiramente na revista Qorpus (KILANOWSKI, 2014) e republicado na antologia Lira argenta (MENDONÇA (org.), 2017, p. 327).

xxi Em português, além do livro (FICOWSKI, Jerzy. A leitura das cinzas. Tradução e organização Piotr Kilanowski. Belo Horizonte-Veneza: Âyiné, 2018), há também duas publicações contendo poemas do livro (KILANOWSKI, 2017b e KILANOWSKI, 2015a).

xxii Em português, além do livro (ŚWIRSZCZYŃSKA, Anna. Eu construia a barricada. Tradução e organização de Piotr Kilanowski. Curitiba: Dybbuk, 2017) há duas seleções dos poemas do livro em minha tradução (KILANOWSKI, 2017c, e KILANOWSKI, 2017a) e uma outra seleção em tradução de Olga Kempińska (KEMPINSKA, 2015). Dois poemas do livro foram traduzidos também por Marcelo Paiva de Souza (MIŁOSZ, 2012, p. 119-120).

xxiii Dois outros poemas seus foram traduzidos por Aleksandar Jovanović (JOVANOVIĆ, 1996, p. 98, republicado na antologia da revista Poesia Sempre) e Marcelo Paiva de Souza (MIŁOSZ, 2012, p.123)

${ }^{\text {xxiv }}$ Um outro poema seu traduzido para o português, Longevidade dos verdugos (JOVANOVIĆ, 1996, p.170), foi republicado na antologia da revista Poesia Sempre.

${ }^{x x v}$ Um outro poema seu, Poesia, foi traduzido por Aleksandar Jovanović (JOVANOVIĆ, 1996, p. 169)

${ }^{x x v i}$ Dois de seus poemas traduzidos e republicados na antologia da revista Poesia Sempre foram originalmente publicados na revista Aproximações (Eliade) e no livro Céu vazio (JOVANOVIĆ, 1996, p. 166) (Derrota).

xxvii Seus poemas em português foram publicados em Aproximações e incluídos na antologia Versos polacos, além de serem traduzidos por Tomasz Łychowski (ŁYCHOWSKI, 2016).

xxviii De acordo com meus conhecimentos esta é primeira publicação do poeta em português.

xxix Uma seleção de poemas de Różycki e uma entrevista com o poeta foram publicados no blogue Escamandro. É dessa seleeção que provém o poema aqui apresentado. Disponível em: https://escamandro.wordpress.com/2019/03/05/tomasz-rozycki-por-rob-packer-e-piotr-kilanowski/, acesso em: 18.07.2019.

${ }^{x x x}$ Em dezembro de 2019, a revista Suplemento Pernambuco publicou uma seleta de seus poemas em minha tradução (KILANOWSKI, 2019c). A editora Âyiné está preparando o primeiro livro de seus poemas em português traduzidos por mim para ser publicado em 2020. 